\title{
Penerapan Layanan Bimbingan Kelompok dalam Mencegah Kenakalan Remaja
}

\author{
Khairil Syahputra*, M. Edwar Romli, Nurlela Nurlela \\ Universitas PGRI Palembang, Indonesia \\ @khairilsyahputra29@yahoo.com
}

Submitted:
2020-03-24
Revised:
2020-05-12
Accepted:
2020-05-19
Copyright holder:
O Syahputra, K., Romli, M. E., \& Nurlela, N. (2020)
This article is under:
CC
How to cite:
Syahputra, K., Romli, M. E., \& Nurlela, N. (2020). Penerapan
Layanan Bimbingan Kelompok dalam Mencegah Terjadinya
Kenakalan Siswa. Bulletin of Counseling and Psychotherapy, 2(1).
Published by:
Kuras Institute
Joumal website:
https://journal.kurasinstititute.com/index.php/bocp
E-ISSN:
2656-1050

2656-1050

\begin{abstract}
The problem in this study is that there are often deviations in student behavior which results in students breaking the rules of discipline at school. Namely skipping school, often late, smoking and fighting. This study aims to determine whether the application of group counseling services in preventing the delinquency of juvenile students in SMA Negeri 9 Palembang effectively. The research method used is a quantitative approach with pre experimental methods with OneGroup Pretest and Posttest Design. The subjects of this study were students of class XI IPS 1 of SMA Negeri 9 Palembang with a sample of 10 students. From the results of data analysis shows that the total pretest value before treatment was 586 with an average of 58.6 and the results of the posttest after being treated with a value of 842 with an average of 84.2. Hypothesis testing results prove that the results of the t-test calculations where $t$-count $=5.039 \geq t$-table $=1.833$. thus the application of group guidance services in preventing juvenile delinquency from students is effectively accepted.
\end{abstract}

KEYWORDS: group guidance; juvenile delinquency; preventive action

\section{PENDAHULUAN}

Pendidikan di Indonesia terus dikembangkan dari waktu-ke waktu agar tercapai tujuan yang tercantum dalam pembukaan UUD 1945. Berbagai kebijakan telah diupayaka agar pendidikan bagi penerus bangsa sesuai dengan tujuan yaitu mencerdaskan kehidupan bangsa. Upaya yang telah dilakukan pemerintah yaitu memungkinkan peserta didik dapat belajar dengan mengembangkan kemampuannya. Idealnya, peserta didik dapat belajar dengan mengembangkan seluruh potensi yang ada pada dirinya (Trinova, 2012).

Sekolah sebagai wadah pendidikan formal mempunyai tanggung jawab besar untuk mewujudkan cita-cita bangsa yang diamanahkan dalam UUD (undang-undang) sistem pendidikan, pendidikan nasional berfungsi mengembangkan kemampuan dan membentuk watak serta peradaban bangsa, bertujuan untuk berkembangnya potensi dari peserta didik agar menjadi manusia yang beriman dan bertaqwa kepada Tuhan Yang Maha Esa, berakhlak mulia, sehat, berilmu, cakap, kreatif, mandiri dan menjadi warga Negara yang demokrasi serta bertanggung jawab (Lisdiana, Giyono, \& Widiastuti, 2013).

Sekolah merupakan lembaga pendidikan resmi yang bertanggung jawab untuk memberikan pendidikan kepada siapapun yang berhak termasuk para remaja (siswa). Sekolah sebagai lembaga formal memiliki tugas menyelenggarakan pendidikan melalui proses pembelajaran untuk mengembangkan aspek kemanusiaan dan potensi diri para peserta didik, sehingga siswa bisa berkembang sesuai dengan potensi yang dimilikinya. Sekolah sebagai lembaga pendidikan formal bertanggung jawab dalam menunjang keberhasilan peserta didiknya menjalankan tugas-tugas 
perkembangannya dengan baik, dan menyediakan program yang menarik, menyenangkan, menantang, membangun motivasi dan memberi kesempatan kepada siswa untuk melakukan kegiatan positif.

Remaja adalah masa peralihan dari kanak-kanak ke dewasa (Saputra \& Lidyawati, 2019). Untuk seorang remaja sudah tidak lagi dapat dikatakan sebagai kanak-kanak, namun ia masih belum cukup matang untuk dapat dikatakan dewasa. la sedang mencari pola hidup yang paling sesuai baginya dan inipun sering dilakukan melalui metode coba-coba walaupun melalui banyak kesalahan. Kesalahan yang dilakukannya sering menimbulkan kehawatiran serta perasaan yang tidak menyenangkan bagi lingkungannya, dan orangtuanya. Dari kesalahan yang diperbuat para remaja hanya akan menyenangkan teman sebayanya. Hal ini merupakan karena mereka semua memang sama-sama masih dalam masa mencari identitas. Kesalahan-kesalahan yang menimbulkan kekesalan lingkungan inilah yang sering disebut sebagai kenakalan remaja.

Remaja merupakan aset masa depan suatu bangsa. Di samping hal-hal yang menggembirakan dengan kegiatan remaja pada waktu yang akhir-akhir ini dan pembinaan yang dilakukan oleh organisasi-organisasi pelajar dan mahasiswa, kita melihat pula arus kemorosotan moral yang semakin melanda di kalangan sebagian pemuda-pemuda kita, lebih terkenal dengan sebutan kenakalan remaja.Dalam suratkabar sering kali kita membaca berita tentang perkelahian pelajar, penyebaran narkotika, pemakaian obat bius, minuman keras, penjambret yang dilakukan oleh anakanak yang berusia belasan tahun, meningkatnya kasus-kasus kehamilan di kalangan remaja putri dan lain sebagainya (Sumara, Humaedi, \& Santoso, 2017)

Hal tersebut adalah merupakan suatu masalah yang dihadapi masyarakat yang kini semakin marak, Oleh karena itu masalah kenakalan remaja seharusnya mendapatkan perhatian yang serius dan terfokus untuk mengarahkan remaja ke arah yang lebih positif yang titik beratnya untuk terciptanya suatu sistem dalam untuk menanggulangi kenakalan di kalangan remaja.

Kenakalan remaja yang biasa disebut dengan istilah juvenile yang berasal dari bahasa latin juvenilis, yang artinya anak-anak, atau anak muda, sifat khas pada remaja, sedangkan delinquency berasal dari bahasa latin delinquere yang berarti terabaikan, mengabaikan, yang kemudian artinya diperluas menjadi jahat, nakal, anti sosial, kriminal, pelanggar aturan, pembuat ribut, dan sebagainya. Kenakalan remaja adalah perilaku jahat atau kenakalan anak-anak muda. Maka dapat disimpulkan bahwa kecenderungan kenakalan remaja adalah kecenderungan remaja untuk melakukan tindakan yang melanggar aturan yang dapat mengakibatkan kerugian dan kerusakan hak terhadap dirinya sendiri maupun orang lain (Unayah \& Sabarisman, 2016).

Untuk kenakalan remaja dilingkungan sekolah yaitu adalah sebagai siswa, jadi pada kenakalan remaja yang dilakukan oleh siswa dapat dikatakan sebagai kenakalan siswa. Dari pengertian ini dapat dikatakan kenakalan siswa adalah tindakan penyimpangan perilaku siswa yang berakibatkan siswa melanggar aturan, tata tertib sekolah dan masyarakat (Aviyah \& Farid, 2014).

Di lingkungan sekolah, kepala sekolah yang berwenang untuk dalam pelaksanan hukuman terhadap pelanggaran tata tertib sekolah. Dalam beberapa hal, guru juga berhak untuk bertindak. Akan tetapi hukuman yang berat seperti skorsing maupun pengeluaran dari sekolah merupakan wewenang dari kepala sekolah. Guru dan staf pembimbing bertugas menyampaikan data mengenai pelanggaran dan kemungkinan-kemungkinan pelanggaran maupun akibatnya. pada umumnya untuk tindakan represif diberikan dalam bentuk memberikan peringatan secara lisan maupun tertulis kepada pelajar dan orang tua, melakukan pengawasan khusus oleh kepala sekolah dan tim guru atau pembimbing dan melarang bersekolah untuk sementara waktu (skor) atau seterusnya tergantung dari jenis pelanggaran tata tertib sekolah (Sumara, Humaedi, \& Santoso, 2017).

Bimbingan kelompok merupakan salah satu bentuk usaha pemberian bantuan kepada orangorang yang mengalami masalah. Suasana kelompok yaitu antar hubungan dari semua orang yang terlibat dalam kelompok, dapat menjadi wahana dimana masing-masing anggota kelompok tersebut 
Syahputra dkk. - Penerapan Layanan Bimbingan ...

secara perseorangan dapat memanfaatkan semua informasi, tanggapan kepentingan dirinya yang bersangkutan dengan masalahnya tersebut.

Berdasarkan dari hasil observasi di sekolah SMA N 9 Palembang Selama Praktik Pengalaman Lapangan (PPL). adapun data yang diperoleh dari hasil pengamatan bahwa siswa di sekolah SMA N 9 Palembang Mempunyai Masalah Kurang disiplin terhadap waktu dan tidak menaati peraturan. membolos, tidak memakai seragam dengan lengkap, bullying, berkelahi, dan merokok.

Maka dari itu Peneliti tertarik untuk melakukan Penerapan Layanan Bimbingan Kelompok Dalam Mencegah terjadinya kenakalan remaja siswa di SMA N 9 Palembang

\section{METODE}

Metode penelitian yang digunakan ialah pendekatan kuantitatif dengan metode pre experimental design sering sekali dipandang sebagai eksperimen yang tidak sebenarnya oleh karena itu, sering disebut quasi exsperiment (Arikunto, 2010).

Menurut Sugiyono (2008) Populasi adalah wilayah generalisasi yang terdiri atas obyek/subyek yang mempunyai kuantitas dan karakteristik tertentu yang ditetakan oleh peneliti untuk dipelajari dan kemudian ditarik kesimpulannya. berikut jumlah populasi siswa kelas XI di SMA Negeri 9 palembang

Sampel adalah sebagian atau wakil populasi yang akan diteliti (Arikunto, 2010). Dari jumlah populasi kelas XI di atas, maka teknik pengambilan sampel dalam penelitian ini menggunakan sampel bertujuan (purposive sample). (Purposive sample) dilakukan dengan cara mengambil subjek bukan didasarkan atas strata. Teknik ini biasanya dilakukan karena beberapa pertimbangan, misalnya alasan keterbatasan waktu, tenaga, dan dana sehingga tidak dapat mengambil sampel yang besar dan jauh (Arikunto, 2010). Maka dari itu sampel yang diambil adalah kelas XI IPS I.

\section{HASIL DAN PEMBAHASAN}

Penelitian ini untuk bertujuan untuk mengetahui penerapan layanan bimbingan kelompok dalam mencegah terjadinya kenakalan remaja siswa SMA Negeri 9 Palembang. Penelitian ini diawali melakukan pretest kenekalan remaja, pemberian perlakuan dilakukan 3 kali pertemuan dengan materi, bolos sekolah, perkelahian dan kriminalitas dengan mengunakan Pretest-Posttest berfungsi untuk membandingkan sesudah dan sebelum diberikan perlakuan sehingga dapat deketahui lebih akurat perbedaannya.

Hasil pengujian hipotesis membuktikan bahwa hasil perhitungan uji-t dimana t-hitung $=5,039 \geq \mathrm{t}$-tabel $=1,833$ pada taraf signifikat 0,5 dengan derajat perbedaan $\mathrm{db}=\mathrm{N}-1$ yaitu 10-1=9 maka hipotesis nol ( $\mathrm{Ha}$ ) layanan bimbingan kelompok tidak dapat mencegah kenakalan remaja sehingga alternatif $(\mathrm{Ha}$ ) diterima dengan demikian penerapan layanan bimbingan kelompok dalam mencegah terjadinya kenakalan remaja efektif diterima. Pelaksanaan perlakuan bimbingan kelompok pada kelompok eksperimen di atas, yang dilakukan secara sistematis dan sesuai prosedur. Setelah dilakukan kegiatan bimbingan kelompok, anggota kelompok sudah dapat memahami topik yang telah dibahas dalam setiap kali pertemuan dan memahami tentang kenakalan remaja disekolah.

Dengan adanya layanan bimbingan kelompok untuk dapat memahami tentang kenakalan remaja pada siswa, karena didalam layanan bimbingan kelompok memanfaatkan dinamika kelompok, dan saling berdiskusi, mengembangkan pendapat dan pengetahuan yang baru.hal tersebut sejalan dengan tujuan bimbingan kelompok yang dikemukakan oleh Tohirin (2013) yaitu secara umum layanan bimbingan kelompok bertujuan untuk mengembangkan kemampuan bersosialisasi. Secara lebih khusus layanan bimbingan kelompok bertujuan untuk mendorong pengembangan perasaan, pikiran, persepsi, wawasan dan sikap yang menunjang perwujudan tingkah laku yang efektif. 


\section{KESIMPULAN}

Berdasarkan dari hasil analisis data maka dapat disimpulkan bahwa penerapan layanan bimbingan kelompok dalam mencegah terjadinya kenakalan remaja siswa SMA N 9 Palembang efektif. Dalam kegiatan layanan bimbingan kelompok terjadi proses sosialisasi antara anggota kelompok, mengemukakan pendapat dan saling menukar informasi, Dan memahami tentang materi yang disampaikan, sehingga mendapatkan wawasan yang baru.

\section{DAFTAR PUSTAKA}

Trinova, Z. (2012). Hakikat Belajar dan Bermain Menyenangkan bagi Peserta Didik. Al-Ta Lim Journal, 19(3), 209-215.

Lisdiana, E., Giyono, G., \& Widiastuti, R. (2013). Penggunaan Layanan Bimbingan Kelompok Teknik Diskusi Untuk Mengurangi Kenakalan Remaja Siswa. ALIBKIN (Jurnal Bimbingan Konseling), 2(2).

Saputra, R., \& Lidyawati, Y. (2019). Self-Instruction Technique in Group Counseling to Reduce Students' Academic Procrastination Behavior. Islamic Guidance and Counseling Journal, 2(2), 49-55.

Sumara, D. S., Humaedi, S., \& Santoso, M. B. (2017). Kenakalan remaja dan penanganannya. Prosiding Penelitian dan Pengabdian kepada Masyarakat, 4(2).

Unayah, N., \& Sabarisman, M. (2016). Fenomena kenakalan remaja dan kriminalitas. Sosio informa, 1(2).

Aviyah, E., \& Farid, M. (2014). Religiusitas, kontrol diri dan kenakalan remaja. Persona: Jurnal Psikologi Indonesia, 3(02).

Arikunto, S. (2010). Prosedur Peneltian (Edisi Revisi). Jakarta: Rineka Cipta.

Sugiyono, S. (2008). Metode penelitian pendidikan:(pendekatan kuantitatif, kualitatif dan $R$ \& D). Alfabeta.

Tohirin, T. (2013). Bimbingan dan KonSeling di Sekolah dan Madrasah (Berbasis Integrasi). Jakarta: Rajawali Pers. 